\title{
BROADBAND ECOSYSTEM ELEMENTS IN TECHNO-ECONOMIC MODELLING AND ANALYSING OF BROADBAND ACCESS SOLUTIONS FOR RURAL AREAS
}

\author{
Višnja Križanović Čik, Drago Žagar, Snježana Rimac-Drlje
}

Original scientific paper

Encouraged by broadband development initiatives and strategies that aim at the reduction of the existing digital divide between rural and urban European areas by the year 2020, the current situation in the case study of Croatian rural broadband market is analysed, and the possibilities for further broadband Internet access implementation in rural areas are highlighted in the paper within the context of broadband ecosystem elements analysis. Furthermore, in order to address the exisiting digital divide problem, an extended techno-economic modelling process for rural broadband Internet access implementation analyses is proposed. The proposed additional part of model serves as an upgrade for the standard techno-economic models and allows a detailed analysis of the specificities of different rural areas, based on the available data. Finally, the efficiency of the proposed model's application when choosing the best business strategies for different fixed and mobile, wired and wireless broadband access solutions in rural areas is presented.

Keywords: broadband ecosystem; broadband implementation; rural broadband access; techno-economic modelling

\section{Elementi širokopojasnog ekosustava pri tehno-ekonomskom modeliranju i analiziranju širokopojasnih pristupnih rješenja za ruralna područja}

Izvorni znanstveni članak S obzirom na postojeće razvojne inicijative i strategije čiji je cilj smanjenje postojećeg digitalnog jaza između europskih ruralnih i urbanih područja do 2020. godine, u radu je provedena analiza trenutnog stanja na tržištu širokopojasnog Interneta na primjeru hrvatskih ruralnih područja te su navedene mogućnosti daljnje implementacije širokopojasnih pristupnih rješenja u ruralna područja u kontekstu analize elemenata širokopojasnog ekosustava. Nadalje, u cilju rješavanja postojećeg problema digitalnog jaza, pri analizama načina implementacije širokopojasnih pristupnih rješenja u ruralnim područjima predložena je primjena proširenog tehno-ekonomskog modeliranja. Navedeno proširenje nadograđuje standardne modele, a omogućuje detaljniju analizu specifičnosti različitih pristupnih rješenja za ruralna područja. U posljednjem dijelu rada prikazana je mogućnost primjene predloženog modela pri odabiru najboljih poslovnih strategija za različita fiksna i mobilna, žična te bežična širokopojasna pristupna rješenja za ruralna područja.

Ključne riječi: širokopojasni ekosustav; širokopojasni pristup u ruralnim područjima; tehno-ekonomsko modeliranje; uvođenje širokopojasnog pristupa

\section{Introduction}

Broadband Internet services present an effective means of delivering digital information to users. Hence, a need for broadband services is continually growing as residential and business users demand ubiquitous highspeed Internet access. Broadband Internet services enhance the quality of life of residential users and increase economic development and productivity for business users [1]. Furthermore, broadband services are promising services for rural areas as well since they can bring substantial social and economic benefits to rural residents [2]. For instance, broadband Internet access enables remote access to health care and education and expands the market potential for rural businesses. Moreover, broadband implementation in rural areas addresses the inequality in the access to information and communication services, i.e. the digital divide between rural and urban areas [3], as well as some negative perceptions of rural life that lead to depopulation and pauperization of rural areas [4].

Furthermore, there appears to be a positive relation between the increase in broadband penetration rates and the economic growth $[5 \div 7]$, especially when a critical mass of infrastructure is present [8]. Hence, broadband access deployment is encouraged by many national broadband development initiatives and strategies around the world. In the European Union, the Member States' initiatives aim to provide broadband access to all citizens of the European Union and reduce the existing digital gap between rural and urban European areas. The latest European Digital Agenda aims at the delivery of sustainable economic and social benefits from the digital single market based on fast and ultra-fast Internet connections and includes broadband access for all EU citizens [9]. Moreover, the Agenda aims at higher Internet access speeds (30 Mbps or above) by 2020 and $50 \%$ or more of European households subscribing to Internet connections above $100 \mathrm{Mbps}$. In the Republic of Croatia, the development tasks of rural areas result from the strategic development goals, which include Croatian rural areas in equal development with the rural areas of the European Union. Following the Broadband Development Strategy of the Republic of Croatia by the year 2008, a new strategy for the period spanning from 2011 to 2015 is proposed [10]. The Strategy defines broadband deployment in sparsely populated areas in the Republic of Croatia as a key enabler for reducing the digital divide between rural and urban areas of the country.

Considering the benefits and the necessity of broadband access implementation in rural areas, in this paper the possibilities and the methods for the reduction of the existing digital divide are considered. First, within the context of the broadband ecosystem elements analyses, the most important determinants of the broadband adoption, the broadband deployment, and the broadband development processes in rural areas are indicated. In addition, regarding the given digital divide reduction objective, the necessity of application of an additional techno-economic modelling methods for choosing the adequate rural broadband access solutions is emphasized. Furthermore, the extended techno-economic model with an additional framework for analysing specific aspects of broadband access implementation in 
rural areas is proposed. Finally, the efficiency of the proposed methodology in analysing the feasibility and the competitiveness of different broadband access solutions in rural areas is presented.

\section{Broadband ecosystem elements}

The term 'broadband ecosystem' generally implies an interconnection among a variety of different elements related to broadband Internet. Those elements include various broadband solutions and different broadband market participants, as presented in Fig. 1. Broadband solutions, comprised of broadband technologies (broadband network infrastructure and equipment), as well as broadband services (broadband applications and utilities), enable the delivery and application of ubiquitous high-speed Internet access. Thus, broadband solutions can be considered in view of the following processes:

- the adoption process of broadband services;

- the development process of broadband technologies and services; and

- the deployment (i.e. implementation) process of broadband technologies.

All these processes are interrelated, as presented in Fig. 1. Hereafter, the adoption process of broadband services fosters a further development of broadband technologies and services, while depending on the development of these technologies and services. Moreover, the deployment process of broadband technologies depends on the development of broadband technologies and services, but at the same time enables broadband services adoption and usage.

In broadband adoption, development, and deployment processes different broadband market participants are engaged. Therefore, the adoption process of broadband services, i.e. the broadband solutions demand, relates to broadband adoption of the following groups of users: the private users (individuals or households), the social groups (local communities), the business users (organizations), and the public sector (local, regional and national authorities). The development process of broadband technologies and services involves the interests of the industry sector (operators and vendors), local, regional and national authorities, as well as aims and scopes of the adopted national and international broadband development initiatives and strategies. Finally, the deployment process of broadband technologies, i.e. broadband solutions supply, is affected by industry, local and government sector.

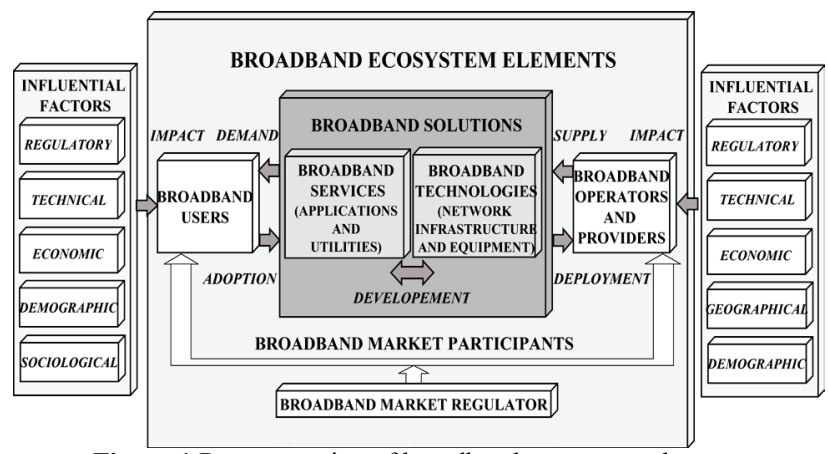

Figure 1 Representation of broadband ecosystem elements
Numerous factors affect broadband demand $[11,12]$ and supply $[13,14]$. Hence, the determination of the most significant factors is not a simple process [15]. An overview of influential factors for broadband deployment and adoption processes, considering broadband solutions' demand and supply sides, is illustrated in Fig. 1.

\section{Rural broadband}

Considering the specificities of rural areas, the deployment of broadband Internet access in rural areas represents a challenging task. Given significant differences between rural and urban areas, as well as differences among various rural area types, the choice of suitable broadband access solutions and their implementation methods in these areas also differ.

Relating to the above mentioned facts, identifying the differences in broadband technologies and services application levels between rural and urban areas is necessary. Based on the results of analyses of broadband application levels, as well as on the results of analyses of broadband access techno-economic aspects, it is possible to propose the most suitable broadband access solutions and strategies for enhancing broadband adoption in rural areas [16]. Hence, understanding the broadband adoption process is essential.

\subsection{Broadband adoption in rural areas}

When analysing the broadband adoption, the broadband development and the broadband deployment processes, areas are generally classified as rural or urban areas. In order to compare the broadband penetration rates in rural and urban areas, and to predict if broadband penetration rates in rural areas could reach the broadband penetration rates of urban areas, a broadband diffusion analysis is conducted for the case study of rural and urban groups of Croatian counties based on data from [17], and the separate results for these groups are presented. According to the EU's criterion, out of twenty one Croatian counties fifteen are classified as rural. The initial presumption that broadband diffusion follows the logistic function curve for both urban and rural groups of counties is proven since given coefficient of determination (R-square) is high, and standard deviation (RMSE) is low. The following expression for the logistic function is used:

$U_{i x}=\frac{a}{1+\mathrm{e}^{-(b+c \cdot x)}}+d_{i x}$,

where $U_{i x}$ represents the number of broadband users per capita in a county $i$ over period $x$; parameter $a$ reflects the long-term level of diffusion; parameter $b$ positions the curve on the timescale; parameter $c$ reflects the speed of broadband adoption and parameter $d_{i x}$ reflects an error term. As presented in Tab. 1, the long run level of diffusion is higher in analysed urban than in rural counties. In the long run, the urban counties converge to an adoption rate of approximately $24 \%$, whereas rural reach a lower adoption rate of approximately $21 \%$.

Fig. 2 presents the average number of broadband users per capita in rural and urban county groups in the 
period spanning from 2002 to 2014 [17]. In addition, the prediction of the future number of users by the year 2020 is conducted using the given logistic function parameters. As shown in Figure 2, at any point in time, the degree of broadband adoption is much lower in rural counties (Logistic RUR) than in urban ones (Logistic URB). Since the parameter reflecting the speed of broadband adoption is higher for urban counties than for rural ones, rural counties cannot reach the long-term adoption rate of urban counties, as presented in Fig. 2.

\begin{tabular}{|c|c|c|c|}
\hline Parameters & \multicolumn{3}{|c|}{ Values (with the $95 \%$ conf } \\
\hline \multicolumn{4}{|c|}{ Logistic_URB } \\
\hline $\mathrm{a}$ & 0,2362 & \multicolumn{2}{|c|}{$(\min 0,2167 ; \max 0,2556)$} \\
\hline $\mathrm{b}$ & $-2,029$ & \multicolumn{2}{|c|}{$(\min -2,329 ; \max -1,73)$} \\
\hline $\mathrm{c}$ & 3,128 & \multicolumn{2}{|c|}{$(\min 2,574 ; \max 3,682)$} \\
\hline $\mathrm{d}$ & $-0,003656$ & \multicolumn{2}{|c|}{$(\min -0,009311 ; \max 0,001999)$} \\
\hline R-square & 0,9971 & RMSE & 0,005253 \\
\hline \multicolumn{4}{|c|}{ Logistic_RUR } \\
\hline $\mathrm{a}$ & 0,2088 & \multicolumn{2}{|c|}{$(\min 0,1895 ; \max 0,228)$} \\
\hline b & $-2,4$ & \multicolumn{2}{|c|}{$(\min -2,643 ; \max -2,158)$} \\
\hline $\mathrm{c}$ & 2,824 & \multicolumn{2}{|c|}{$(\min 2,404 ; \max 3,244)$} \\
\hline $\mathrm{d}$ & $-0,002541$ & \multicolumn{2}{|c|}{$(\min -0,006043 ; \max 0,0009618)$} \\
\hline R-square & 0,9982 & RMSE & 0,003245 \\
\hline
\end{tabular}

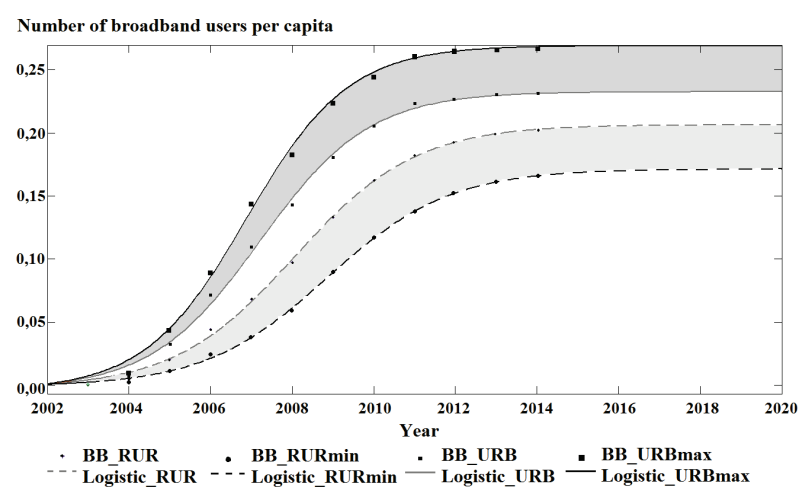

Figure 2 Broadband users in croatian counties

The given estimates suggest that the digital divide between the analysed rural and urban counties exists and may be difficult to eliminate within the period defined by the Digital Agenda. Hence, the methods for the digital divide reduction should be closely defined and applied.

\subsection{Methods for digital divide reduction}

There are several methods for the digital divide reduction [18]. The first digital divide reduction method includes the encouragement of further adoption of broadband solutions through the development of new broadband services [19]. The developed services should be adjusted to the requirements and needs of the rural residents. Such services allow the users easier communication, access to relevant digital information sources, acquisition of new knowledge through the use of on-line educational content, teleworking, etc. In Fig. 3, the correlation between the number of available broadband services and the number of broadband users in Croatia in the early broadband adoption period is presented [20]. As presented in Fig. 3, the increase in the volume of available broadband services correlates with the increse in the number of broadband users. As shown in Fig. 3, at the beginning of broadband services introduction in Croatia, the key factor for broadband adoption was the volume of available high-level broadband services. The positive trends in the increase of high-level services followed by the increase in the number of broadband users have continued, and this demonstrates the importance of availability of broadband services for broadband adoption.

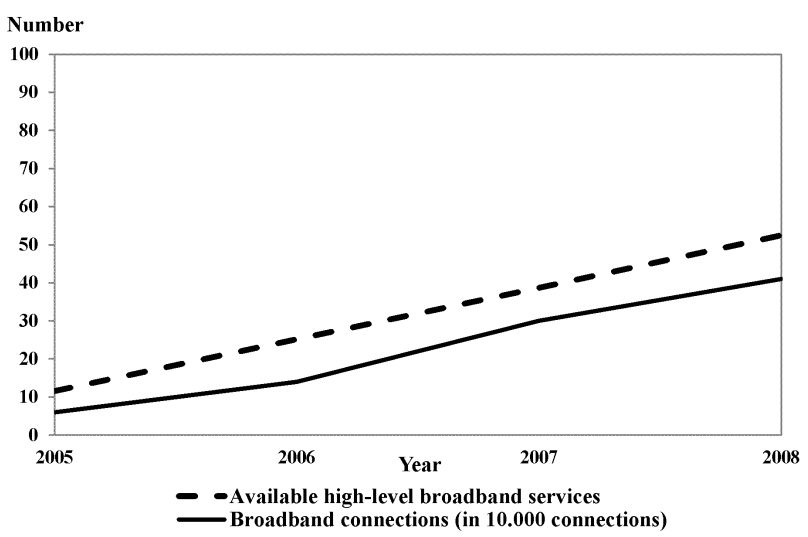

Figure 3 Broadband Services and Connections

Other digital divide reduction methods include coordination of broadband services prices with the rural residents income levels, as well as further fostering of digital literacy of rural residents $[21,22]$. The correlations between the percentage of broadband connections per capita and the portion of broadband Internet users according to their employment status, educational level, and age structure can be examined [23, 24]. In Fig. 4, the positive correlations between the broadband users and the employed (population making income), younger and higher educated population can be noticed [25].

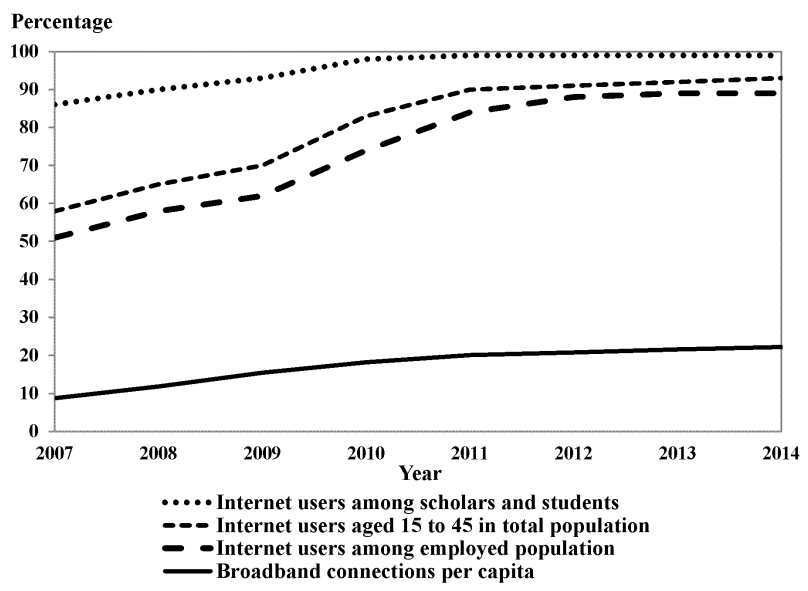

Figure 4 Broadband connections and users

Finally, one of the digital divide reduction methods is also the encouragement of further deployment of broadband technologies, i.e. broadband access network infrastructure [9]. The European national initiatives and strategies, including the Croatian Broadband Development Strategy [10], oblige all public entities and institutions, businesses and private sectors to equal development for the future knowledge-based information society and define communication technologies and services as important factors in achieving the economic 
growth and prosperity. Therefore, further deployments of broadband access infrastructure and an upgrade of the existing wired and wireless infrastructure with new broadband technologies are recommended [26]. All wireline (xDSL, the next generation FTTH and HFC) as well as all wireless (fixed and mobile WiMAX, Wi-Fi, the $2^{\text {nd }}$ generation: GSM/GPRS/EDGE, the $3^{\text {rd }}$ generation: UMTS/HSPA/HSPA+ and the $4^{\text {th }}$ generation: LTE) networks deployments are included in the achievement of the defined goals [9]. The comparison of broadband access technologies according to their implementation process is given in the Tab. 2. In areas with a low population density - rural areas, the Croatian Strategy encourages further implementation of $\mathrm{xDSL}$ as well as WiMAX, UMTS/HSPA/HSPA+ and LTE.

Table 2 Overview of broadband access technologies

\begin{tabular}{|c|c|c|c|c|}
\hline Access solution & Implementation: & $\begin{array}{l}\text { Pre-existing } \\
\text { access } \\
\text { infrastructure: }\end{array}$ & Transmission: & $\begin{array}{l}\text { Terminal } \\
\text { equipment: }\end{array}$ \\
\hline xDSL & $\begin{array}{l}\text { building a completely new access network } \\
\text { infrastructure or an upgrade of the existing } \\
\text { infrastructure of public switched telephone } \\
\text { network }\end{array}$ & \multirow{4}{*}{$\begin{array}{l}\text { cabel ducts, } \\
\text { network } \\
\text { equipment } \\
\text { co-location } \\
\text { spaces }\end{array}$} & $\begin{array}{l}\text { wired; copper pairs / optical } \\
\text { fibres }\end{array}$ & fixed \\
\hline $\mathrm{HFC}$ & $\begin{array}{l}\text { building a completely new access network } \\
\text { infrastructure or an upgrade of the existing } \\
\text { infrastructure of cable TV network }\end{array}$ & & $\begin{array}{l}\text { wired; combination of optical } \\
\text { and coaxial cables }\end{array}$ & fixed \\
\hline FTTH & $\begin{array}{l}\text { building a completely new access network } \\
\text { infrastructure }\end{array}$ & & $\begin{array}{c}\text { wired; } \\
\text { optical fibres }\end{array}$ & fixed \\
\hline PLC & $\begin{array}{l}\text { upgrade of the existing infrastructure of } \\
\text { powerline network }\end{array}$ & & $\begin{array}{l}\text { wired; low- and medium- } \\
\text { voltage cables }\end{array}$ & fixed \\
\hline Wi-Fi & installation of new access network equipment & \multirow{3}{*}{$\begin{array}{l}\text { antenna } \\
\text { towers, } \\
\text { network } \\
\text { equipment } \\
\text { co-location } \\
\text { spaces }\end{array}$} & $\begin{array}{l}\text { wireless; unlicenced radio } \\
\text { frequency spectrum }\end{array}$ & mobile \\
\hline WiMAX & $\begin{array}{l}\text { building a completely new access network } \\
\text { infrastructure }\end{array}$ & & $\begin{array}{l}\text { wireless; licenced or } \\
\text { unlicenced radio frequency } \\
\text { spectrum }\end{array}$ & mobile or fixed \\
\hline $\begin{array}{l}\text { UMTS/ HSPA/ } \\
\text { LTE }\end{array}$ & $\begin{array}{l}\text { building a completely new access network } \\
\text { infrastructure or an upgrade of the existing } \\
\text { infrastructure of mobile network }\end{array}$ & & $\begin{array}{l}\text { wireless; licenced radio } \\
\text { frequency spectrum }\end{array}$ & mobile \\
\hline Satellite & $\begin{array}{c}\text { installation of new access network terminal } \\
\text { equipment }\end{array}$ & - & $\begin{array}{l}\text { wireless; licenced radio } \\
\text { frequency spectrum }\end{array}$ & mobile or fixed \\
\hline
\end{tabular}

\section{Techno-economic modelling}

In order to encourage further implementation of broadband solutions, i.e. broadband access network infrastructure, it is necessary to identify the most important factors associated with the implementation of broadband access infrastructure in rural areas, choose the most appropriate and cost-effective broadband access solutions for rural areas, and enable their further implementation by adopting the best strategies [27]. In this way, the increase in the total number of broadband users and the reduction of the existing digital divide could be achieved [28].

Moreover, pure technical superiority is not a guarantee of market success for new broadband access technologies in the telecommunications market [29]. Social, demographic, geographic, economic and regulatory issues all play an important role in network rollout and broadband service offerings [30]. All these issues have a direct impact on the viability and the costeffectiveness of broadband access deployment projects [31]. Hence, the detailed techno-economic analyses of access networks deployments are essential.

However, as defined within the broadband ecosystem elements interconnection, despite the broadband network infrastructure availability, the availability of broadband services is essential for broadband adoption and development. Therefore, when considering broadband solutions, it is necessary to consider the relevance of broadband services for users.

The issues discussed in this paper relate to achieving a balance between demands of potential and existing users of rural broadband services and the interests of network operators. For further analysis, it is assumed that the broadband users' requests include the reduction in service prices, the increases of the service quality, the amount of traffic, and the service access speed. In addition, it is assumed that the operators' interests include an increase in service revenues and the reduction of expenditures for the defined demands on area coverage, capacity and access speed, as presented in Fig. 5.

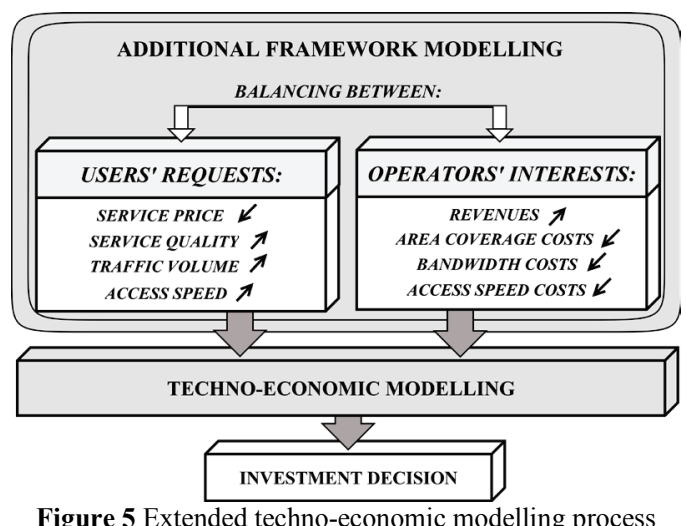

Finally, it is assumed that the balance between the users' requests and the operators' interests which include the cost-effective business models can be achieved through changes of per-user revenues, coverage area, per-user bandwidth and per-user access speed.

\section{Extended techno-economic model}

Taking numerous specificities of rural areas into account, the introduction of broadband access in these 
areas calls for special consideration. Hence, it is necessary to define a techno-economic model with focus placed on deployment of broadband access considering specificities of rural areas. The model should connect the needs of users in rural areas and the interests of network operators, and this should result in a better adequacy of the proposed solutions for broadband access implementation in rural areas.

A lack of criteria necessary for the evaluation of rural broadband deployment based on the analyses of key factors is evident. That criteria should indicate the adequacy of broadband access deployment in rural areas, even in the cases in which the cost-effectiveness is not significant. Hence, the existing techno-economic modelling processes defined in $[32 \div 34]$, could be adapted for the analyses of broadband access deployment in rural areas and expanded with an additional framework, which should include criteria based on the interests of operators, and also on the requirements of potential end-users in rural areas. Hence, the proposed extended technoeconomic model, presented in Figure 6., includes not only several standard frameworks for modelling of market and services, industrial architectures, technical architectures (i.e. technical planning and dimensioning of access network solutions), revenues, costs, economical and financial aspects, and profitability; but also one additional novel framework.

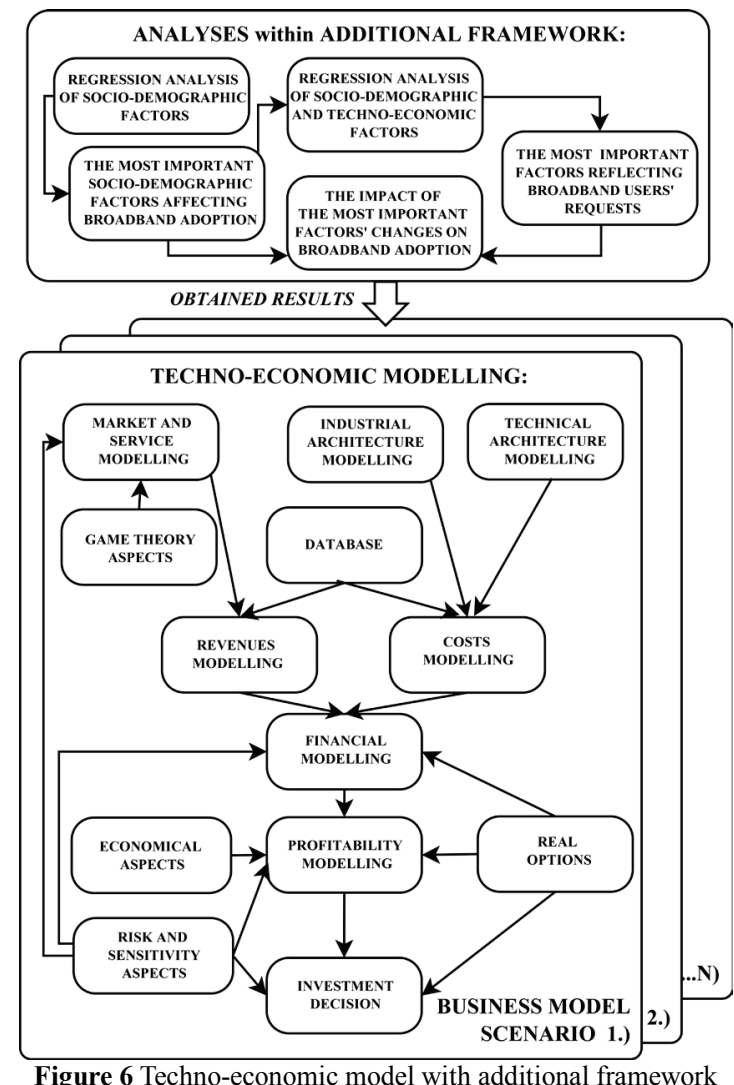

\subsection{Analyses within additional framework}

The proposed novel part of the model, i.e. an additional framework, allows supplementary analyses of existing needs and requirements of end-users, necessary for further planning of access networks and determination of the best business models and strategies for operators.
The proposed framework defines the analyses of available data and the requirements of end-users as an important part of the research, needed to provide the necessary input to the techno-economic model. Thus, unlike the results of other end-users data analyses conducted so far [23, 24, 35 ], the results obtained through analyses carried out within this framework are directly included in the technoeconomic modelling processes. In the proposed additional framework of the techno-economic model several data analyses listed hereafter are implemented.

A) The regression analysis and determination of the most important socio-demographic factors that define and affect the number of broadband users:

Aiming at the identification of the appropriate strategies for increasing broadband adoption volume in rural areas and the reduction of the existing digital divide, the most important socio-demographic factors affecting broadband adoption could be examined using the regression analyses. The data required for analyses are the average income per capita, the average population density, the educational and the age structure of the population, the proportion of the working labour, the proportion of the labour working in the primary business sector, typical for rural areas, and the number of broadband users in the previous period. Hence, to identify the main factors affecting the broadband adoption expressed through $\beta$ coefficients, the following model, obtained from a nonlinear model, could be used:

$\ln ($ number_of_users $)=\beta_{0}+\beta_{N I} \cdot \ln ($ socio-dem_factor_1 $)+$
$+\ldots+\beta_{N n} \cdot \ln ($ socio-dem_factor_n $)$

The regression analyses results show the most significant socio-demographic factors for broadband adoption in rural counties. For the digital divide analysis, the effects of demographic and the socio-economic factors on the broadband adoption in rural areas can be analysed using the following regression model [43]:

$$
\begin{aligned}
& \ln \left(U_{i x}\right)=\beta_{0}+\beta_{1} \cdot \ln \left(\text { Age }_{i x}\right)+\beta_{2} \cdot \ln \left(E d u_{i x}\right)+ \\
& +\beta_{3} \cdot \ln \left(G D P_{i x}\right)+\beta_{4} \cdot \ln \left(\text { Workf }_{i x}\right)+\beta_{5} \cdot \ln \left(\text { Prim_sec }_{i x}\right)+ \\
& +\beta_{6} \cdot \ln \left(\text { Pop_Den }_{i x}\right)+\beta_{7} \cdot \ln \left(U_{i x-1}\right)+\eta_{i}+e_{i x}
\end{aligned}
$$

where $U_{i x}$ represents the number of broadband users in the county $i$ and in the period $x, A g e_{i x}$ is the population aged 15 to 45 , while $E d u_{i x}$ is the population attending secondary school or faculty. $G D P_{i x}$ represents the gross domestic product, Workf $f_{i x}$ the labour (i.e. work) force, Prim_sec $_{i x}$ the labour force working in the primary business sector, Pop_Den ${ }_{i x}$ the population density, and $U_{i x-1}$ the number of broadband users in a given county in the previous year, respectively. The variable $\eta_{i}$ represents a country fixed effect (comprised in the constant term) and $e_{i x}$ is a standard error term.

For the case study, the broadband diffusion analysis is conducted for the rural group of Croatian counties [43]. The given results are presented in Tab. 3 .

For the regression analysis in which the parameter $U_{i x-1}$ is not included in the model (3), the presented results show that the major impact on broadband adoption in rural counties has the population employment status, followed by the population educational structure and the income level. The results show that a $1 \%$ increase in the 
gross domestic product is associated with the approximately $10 \%$ increase in the number of broadband users in both groups of counties. Additionally, in the rural counties, increases of $1 \%$ in the educational and age structure of the population under consideration drive up the broadband connections by $7,23 \%$ and $1,27 \%$, respectively. For the regression analysis in which the parameter $U_{i x-1}$ is included in the model (3), the presented results show that the number of broadband users in a given county in the previous year presents a strong determinant of the number of broadband users in the current year since the number of existing broadband users affects the utility derived from broadband consumption.

Table 3 Estimation of regression model coefficients describing broadband adoption in rural areas

\begin{tabular}{|l|c|c|}
\hline $\begin{array}{c}\text { Nonlinear regression } \\
\text { analysis results } \\
\text { for rural counties }\end{array}$ & $\begin{array}{c}\text { Regression model (3) } \\
\text { without the parameter } \\
U_{i x-1}\end{array}$ & $\begin{array}{c}\text { Regression model (3) } \\
\text { with the parameter } \\
U_{i x-1}\end{array}$ \\
\hline Estimated coefficients: & 1,271 & 0,452 \\
\hline $\ln \left(\right.$ Age $\left._{i x}\right)$ & 7,229 & 1,094 \\
\hline $\ln \left(\right.$ Edu $\left._{i x}\right)$ & 9,942 & 1,140 \\
\hline $\ln \left(G D P_{i x}\right)$ & $-7,875$ & $-0,352$ \\
\hline $\ln \left(\right.$ Workf $\left._{i x}\right)$ & 0,549 & 0,047 \\
\hline $\ln \left(\right.$ Prim_sec $\left._{i x}\right)$ & $-0,497$ & $-0,162$ \\
\hline $\ln \left(\right.$ Pop_Den $\left._{i x}\right)$ & not included & 0,547 \\
\hline $\ln \left(U_{i x-1}\right)$ & $(-81,06)$ & $(-18,12)$ \\
\hline Intercept term & 150 & 150 \\
\hline Statistics: & 0,586 & 0,925 \\
\hline Nr. of observations & & \\
\hline R-squared & \multicolumn{2}{|c|}{} \\
\hline
\end{tabular}

Examining the econometric analysis results, it is obvious that, while aiming at the further encouragement of broadband adoption in rural counties and the closure of the existing digital gap, the appropriate strategies for enhancing broadband adoption should be considered. In relation to the econometric analysis results showing the most significant factors for broadband adoption in rural counties, the proposed strategies may include the additional promotion of the computer literacy of the rural residents, i.e. their further education, and the coordination of the proposed broadband service price levels with the actual rural residents' income levels.

B) The regression analysis and determination of the most important combination of socio-demographic and techno-economic factors that describe the users' requests:

In addition, the techno-economic factors (the user requests on service prices, the quality of service, the traffic volume and the access speed) are included in the regression analysis. The analysis of the obtained data allows the formation of the most important links between the socio-demographic factors and the techno-economic factors. The values of coefficients describe the impact of certain combinations of the most important sociodemographic factors determined in the previous step and the techno-economic factors.

$\ln ($ number_of_users $)=\beta_{0}+$

$+\beta_{K 1} \cdot \ln ($ combination_of_factors_ 1$)+\ldots+$

$+\beta_{K N} \cdot \ln ($ combination_of_factors_N)

As analysis results, the greatest values of coefficients for the combinations involving the four chosen techno- economic factors: the services price, the quality of service, the traffic volume and the access speed (denoted hereafter by $\beta_{1}, \beta_{2}, \beta_{3}$ and $\beta_{4}$, respectively) are considered and included in the further modelling process.

C) The quantitative analysis of the impact of changes in the amount of techno-economic factors on the total number of broadband users:

Finally, the impact of techno-economic factors: the service price $(P)$, the quality of service (which is analysed regarding the service coverage area $(C)$ ), the traffic volume (i.e. available bandwidth $(B)$ ) and the broadband access speed $(S)$, on the total number of users $(U)$ is conducted using the regression analysis of the available data. The influence of certain factors on the total number of users is estimated for the previously obtained $\beta_{1}, \beta_{2}, \beta_{3}$ and $\beta_{4}$ coefficient values:

$$
U=\beta_{1} \cdot P+\beta_{2} \cdot \mathrm{C}+\beta_{3} \cdot B+\beta_{4} \cdot S+\beta_{0}
$$

Furthermore, the possible changes in the technoeconomic factors values (i.e. $\Delta P, \Delta C, \Delta B$ and $\Delta S$ ) that may occur in a future period are considered. Hence, the expression for determining the impact of changes in the techno-economic factors values to the change in the total number of users $(\Delta U)$ can be written as:

$\Delta U=\beta_{1} \cdot \Delta P+\beta_{2} \cdot \Delta C+\beta_{3} \cdot \Delta B+\beta_{4} \cdot \Delta S$

The aim of the further techno-economic modelling process is to determine the best strategies for operators based on the predetermined values of the beta coefficients when considering the impact of changes in technoeconomic factors, i.e. delta factors.

\subsection{Choosing the best operators' strategies}

Several parts of the techno-economic modelling process are affected by a proposed novel modelling methodology. The given delta values are included and have a direct impact on the further techno-economic modelling process - the planning of the scenario's regulatory component (by defining the network targeted coverage area), the planning of the scenario's services component (by defining the available bandwidth per user), the modelling of the access network (by defining the per user access speed), and the modelling of service prices (by defining the per user revenues), as well as at the operator revenues and expenditures determination, and finally at the best operator's strategies determination.

Operator's revenues $(R)$ are modelled in the modified techno-economic process based on the number of broadband users and the service prices. The expression for determining the impact of changes in the values of these two factors on the total revenue can be written in the following form:

$\Delta R=\Delta U \cdot \Delta P \rightarrow \max$.

In the strategies determination process, the scenarios that cause the greatest increase in revenues are chosen.

Operator's expenditures $(E)$ are modelled in the modified techno-economic process based on the coverage 
area, the available bandwidth per user and the access speed per user (that affects the required number of access network infrastructure components). The expression for determining the impact of changes in the values of these factors on the total expenditures (costs) can be written in the following form:

$\Delta E=\Delta U \cdot(\Delta C+\Delta B+\Delta S) \rightarrow \min$.

In the strategies determination process, the scenarios that cause the greatest decrease in expenditures are chosen.

The expression used for determining the impact of parameters changes on the scenarios profitability is:

$\Delta N P V=\Delta R-\Delta E \rightarrow \max$.

Finally, the best operators' strategies are the ones with the greatest $N P V$ values.

Table 4 Overview of conducted comparisons Conducted comparisons $\quad$ Reference

\begin{tabular}{|c|c|c|c|c|c|c|c|c|c|c|}
\hline \multirow{2}{*}{\multicolumn{2}{|c|}{ Conducted comparisons }} & \\
\hline & & [37] & [38] & [39] & [40] & [41] & [42] & [43] & [44] & [45] \\
\hline \multicolumn{11}{|c|}{ Scenarios hierarchy: } \\
\hline \multicolumn{2}{|c|}{$\begin{array}{l}\text { Settlements } \\
\text { (different rural area types) }\end{array}$} & $\checkmark$ & $\checkmark$ & $\checkmark$ & & & $\checkmark$ & & & $\checkmark$ \\
\hline \multicolumn{2}{|c|}{$\begin{array}{l}\text { Municipalities (divided into rural, } \\
\text { suburban and urban parts) }\end{array}$} & & & & & $\checkmark$ & $\checkmark$ & & $\checkmark$ & \\
\hline \multicolumn{2}{|c|}{$\begin{array}{l}\text { Counties (divided into rural, } \\
\text { suburban and urban parts) }\end{array}$} & & & & $\checkmark$ & & & & & \\
\hline \multicolumn{2}{|c|}{$\begin{array}{l}\text { Country } \\
\text { (different rural and urban counties) }\end{array}$} & $\checkmark$ & & & & & & $\checkmark$ & & \\
\hline \multicolumn{11}{|c|}{ Broadband ecosystem elements: } \\
\hline \multicolumn{2}{|c|}{$\begin{array}{l}\text { Broadband network } \\
\text { infrastructure and equipment }\end{array}$} & $\checkmark$ & $\checkmark$ & $\checkmark$ & $\checkmark$ & $\checkmark$ & $\checkmark$ & $\checkmark$ & $\checkmark$ & $\checkmark$ \\
\hline \multicolumn{2}{|c|}{$\begin{array}{l}\text { Broadband applications and } \\
\text { services }\end{array}$} & $\checkmark$ & $\checkmark$ & $\checkmark$ & $\checkmark$ & $\checkmark$ & $\checkmark$ & $\checkmark$ & $\checkmark$ & $\checkmark$ \\
\hline \multirow{3}{*}{$\begin{array}{l}\text { Broadband } \\
\text { market } \\
\text { participants }\end{array}$} & End users & $\checkmark$ & $\checkmark$ & $\checkmark$ & $\checkmark$ & $\checkmark$ & $\checkmark$ & $\checkmark$ & $\checkmark$ & $\checkmark$ \\
\hline & Operators & $\checkmark$ & $\checkmark$ & $\checkmark$ & $\checkmark$ & $\checkmark$ & $\checkmark$ & $\checkmark$ & $\checkmark$ & $\checkmark$ \\
\hline & Regulators & & $\checkmark$ & $\checkmark$ & $\checkmark$ & $\checkmark$ & $\checkmark$ & $\checkmark$ & $\checkmark$ & $\checkmark$ \\
\hline \multicolumn{11}{|c|}{ Broadband access: } \\
\hline \multicolumn{2}{|c|}{ Fixed wired access } & $\checkmark$ & $\checkmark$ & $\checkmark$ & $\checkmark$ & & $\checkmark$ & $\checkmark$ & & \\
\hline \multicolumn{2}{|c|}{ Fixed wireless access } & $\checkmark$ & $\checkmark$ & $\checkmark$ & $\checkmark$ & & $\checkmark$ & $\checkmark$ & $\checkmark$ & \\
\hline \multicolumn{2}{|c|}{ Mobile wireless access } & $\checkmark$ & & & $\checkmark$ & $\checkmark$ & $\checkmark$ & $\checkmark$ & $\checkmark$ & $\checkmark$ \\
\hline \multicolumn{11}{|c|}{ Broadband technology: } \\
\hline \multicolumn{2}{|l|}{ ADSL } & $\checkmark$ & $\checkmark$ & $\checkmark$ & $\checkmark$ & & $\checkmark$ & $\checkmark$ & & \\
\hline \multicolumn{2}{|l|}{ HFC } & $\checkmark$ & & & & & & $\checkmark$ & & \\
\hline \multicolumn{2}{|l|}{ PLC } & $\checkmark$ & & $\checkmark$ & & & & & & \\
\hline \multicolumn{2}{|l|}{ FTTU } & $\checkmark$ & & & & & & $\checkmark$ & & \\
\hline \multicolumn{2}{|c|}{ Fixed WiMAX } & $\checkmark$ & $\checkmark$ & $\checkmark$ & $\checkmark$ & & $\checkmark$ & $\checkmark$ & $\checkmark$ & \\
\hline \multicolumn{2}{|c|}{ Mobile WiMAX } & & & & & $\checkmark$ & $\checkmark$ & $\checkmark$ & $\checkmark$ & \\
\hline \multicolumn{2}{|l|}{ UMTS } & $\checkmark$ & & & $\checkmark$ & & & $\checkmark$ & & $\checkmark$ \\
\hline \multicolumn{2}{|l|}{ LTE } & & & & & $\checkmark$ & $\checkmark$ & $\checkmark$ & & \\
\hline \multicolumn{2}{|l|}{ Satellite } & $\checkmark$ & & & & & & $\checkmark$ & & $\checkmark$ \\
\hline Wi-Fi & & $\checkmark$ & & & & & & & & $\checkmark$ \\
\hline \multicolumn{11}{|l|}{ Methods: } \\
\hline Qualitative a & ysis & $\checkmark$ & & & & & & $\checkmark$ & & \\
\hline Cost-benefit & alysis & $\checkmark$ & & & & & & & & $\checkmark$ \\
\hline Scenario ana & & $\checkmark$ & $\checkmark$ & $\checkmark$ & $\checkmark$ & $\checkmark$ & $\checkmark$ & & $\checkmark$ & $\checkmark$ \\
\hline Sensitivity a & ysis & & $\checkmark$ & $\checkmark$ & $\checkmark$ & $\checkmark$ & $\checkmark$ & & $\checkmark$ & $\checkmark$ \\
\hline Risk analysi & & & & & $\checkmark$ & & & & $\checkmark$ & $\checkmark$ \\
\hline Comparative & alysis & $\checkmark$ & $\checkmark$ & $\checkmark$ & $\checkmark$ & $\checkmark$ & $\checkmark$ & $\checkmark$ & $\checkmark$ & $\checkmark$ \\
\hline Econometric & alysis & & & & & & & $\checkmark$ & & \\
\hline
\end{tabular}

\section{Results}

The objective of the analyses conducted using the defined techno-economic model is to demonstrate how the network operator can come off in the competition with demographics, economical constraints, estimated broadband service demands and regulatory conditions in several types of rural area scenarios. In conducted planning process and the techno-economic modelling processes, users' requirements on price and quality of service, access speed and the amount of traffic are considered. The most important costs associated with the deployment, operation and maintenance of the representative fixed wireline, as well as fixed and mobile wireless broadband access technologies are taken into consideration, and the cost-effectiveness of their implementation in rural areas is determined. Furthermore, a set of technical results and financial results using net present value $(N P V)$ method is presented to show the effects of key factor changes on the overall costs of networks deployments [36].

The choice of broadband access technologies depends on the scenarios size or the existing scenarios hierarchy. Accordingly, depending on the size of the studied area, the following hierarchical levels can be distinguished: the local level (which includes the villages and municipalities), the regional level (which includes the counties and regions) and the national level. Therefore, for selecting the most appropriate technology in rural scenarios, i.e. the most cost-effective access solutions, the analysis should be conducted in a view of the existing hierarchy of scenarios. In Tab. 4, a comparative overview of all conducted analyses of broadband access solutions is presented. An overview of the hierarchical levels of certain scenarios, the analysed types of access solutions and the applied methods are presented. The analyses of possibilities for implementation of different technological solutions and the market overview for different scenarios are given in $[37 \div 45]$. The given conclusions are included into techno-economic modelling process and the obtained results are analysed hereafter.

\subsection{Techno-economic analyses results}

The techno-economic analyses have been carried out to determine the feasibility and the competitiveness of broadband access networks in providing broadband Internet access to residential customers in rural areas. Networks deployments have been analysed in several rural area scenarios. Analyses of broadband access networks deployments in rural areas are conducted for the case study of Croatian market. As a result of conducted techno-economic analyses, the obtained results point to the most cost-effective solutions for operators.

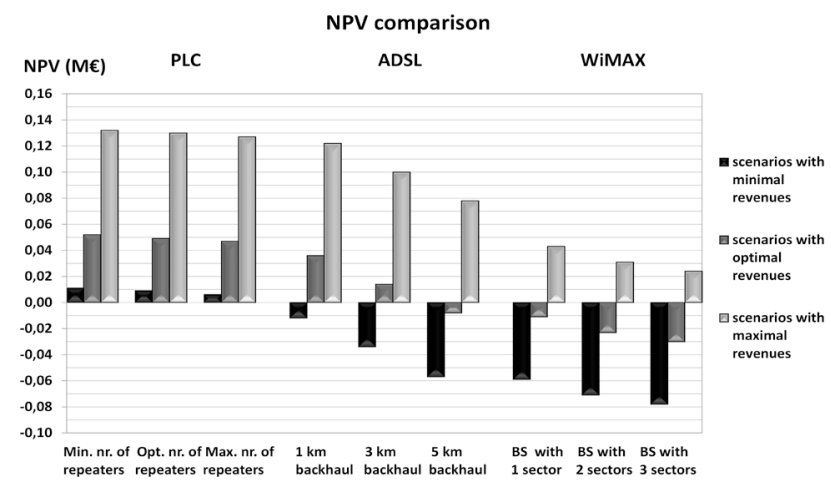

Figure 7 Fixed access in rural settlement scenarios

For different rural local areas scenarios, i.e. rural settlements, the techno-economic analyses of different broadband access solutions have been conducted [39]. The given results show that the most adequate solutions for broadband access are ADSL, WiMAX and PLC, presented in Fig. 7. The most expensive solutions include 
the ones in which a completely new infrastructure is built (e.g. WiMAX). Hence, a priority to an upgrade of the preexisting infrastructure should be given (e.g. PLC and ADSL).

Considering the fact that the digital divide problem also affects the surface of larger areas, scenarios involving broader rural areas than those in the previously presented analyses are created. Furthermore, the technoeconomic comparisons of access technologies on the regional levels are conducted.

The comparison of different fixed access technologies also indicated the fact that all components of the preexisting fixed infrastructure should be used [40]. Hence, as presented in Fig. 8, building a new (e.g. WiMAX) access network is more expensive solution than upgrading the pre-existing network infrastructure (e.g. ADSL).

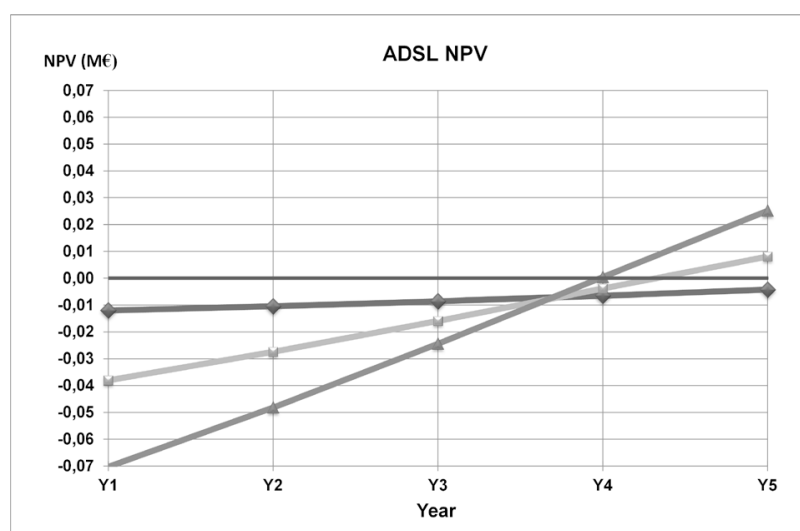

$\rightarrow 10$ USERS, $1 \mathrm{~km}$ BACKHAUL $\backsim 40$ USERS, $5 \mathrm{~km}$ BACKHAUL $₫ 80$ USERS, $10 \mathrm{~km}$ BACKHAUL

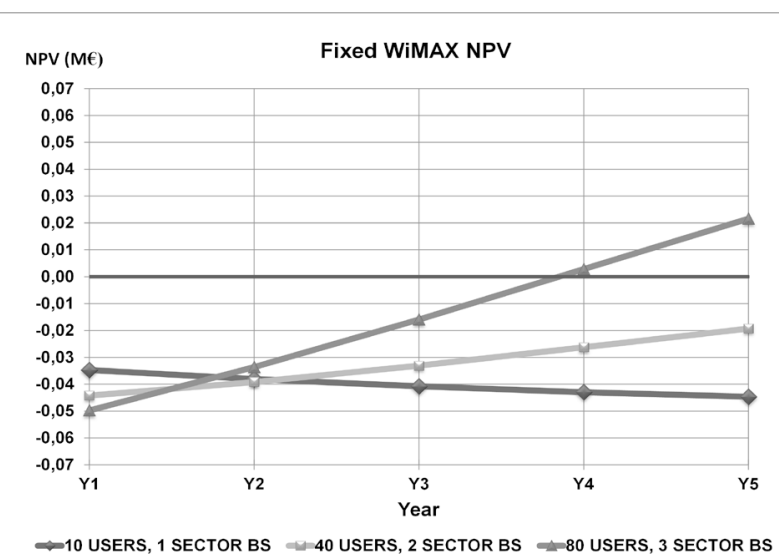

Figure 8 NPV comparison of fixed wired access technologies [40]

Furthermore, the comparison of cost-effectiveness of fixed and mobile networks pointed on the fact that compared to fixed access solutions (e.g. ADSL and fixed WiMAX, presented in Fig. 8), mobile access solutions (e.g. mobile WiMAX and LTE, presented in Fig. 9) have longer return of investment period [41].

Moreover, the comparison of the cost-effectiveness of wired and wireless access networks pointed on the fact that, in the cases of an upgrade of an existing wired infrastructure, the new wireless solutions (e.g. WiMAX) are more expensive ones than the upgraded wired access solutions (e.g. ADSL). However, new mobile access networks (e.g. Mobile WiMAX) present adequate access solutions if fixed access infrastructure (e.g. fixed WiMAX) is not available [44], as presented in Fig. 10.

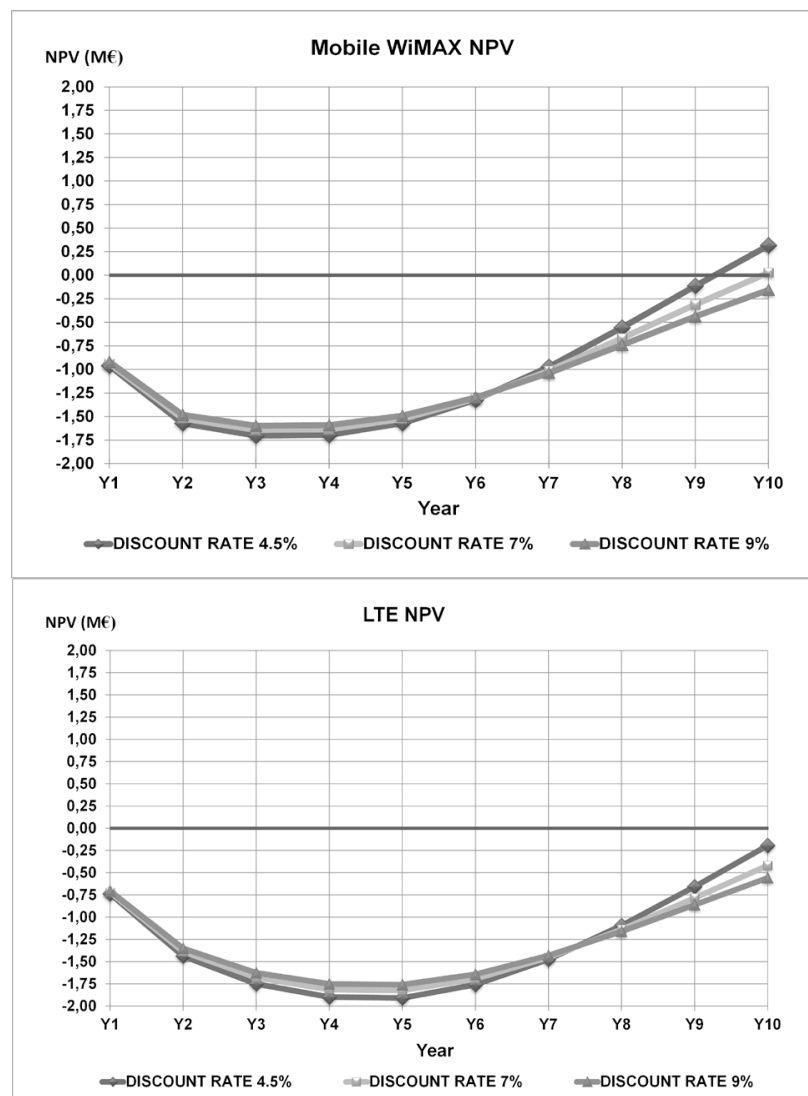

Figure 9 NPV comparison of mobile wireless access technologies [41]

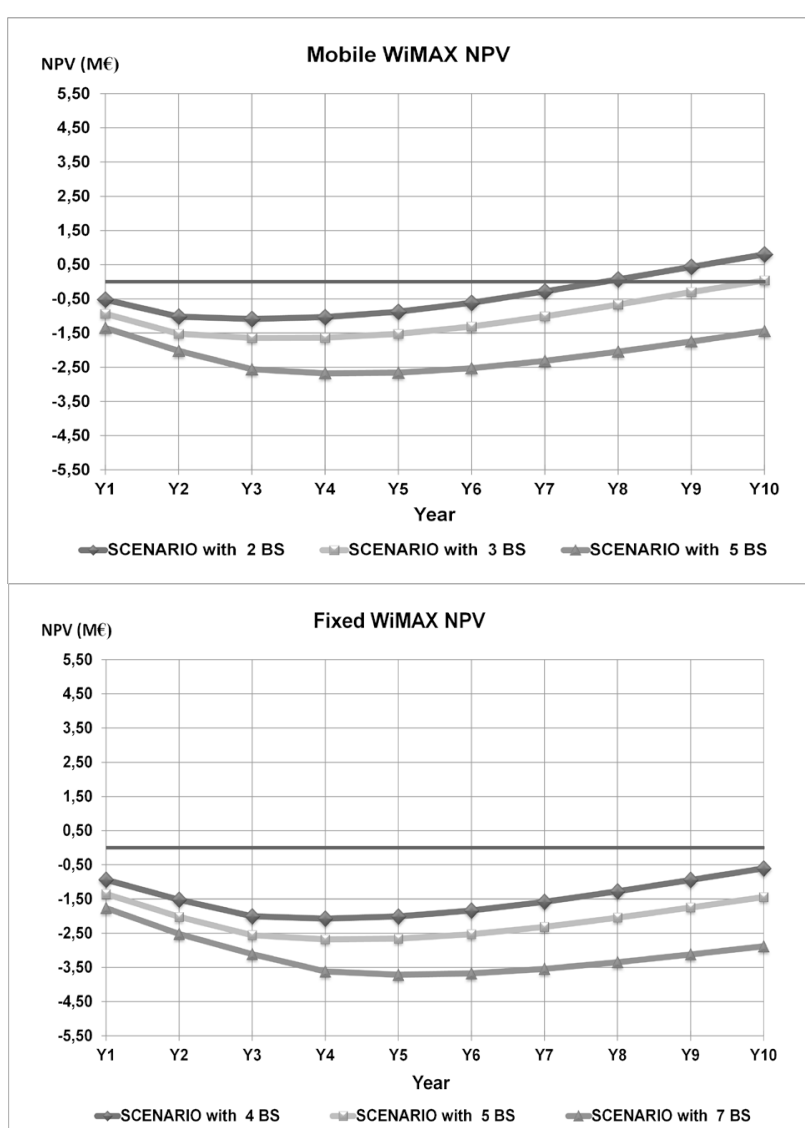

Figure 10 NPV comparison of fixed and mobile wireless access technologies [44]

In addition, the impact of different frequency operating bands, available channel bandwidths, antenna 
elements and coding techniques for coverage enhancement on the overall number of required BSs is analysed in mobile and fixed wireless access network scenarios, as presented in Tab. 5 [44]. The reduction in the required number of $\mathrm{BSs}$ increases the costeffectiveness of analysed access solutions.

Table 5 Wireless access network planning for rural scenarios

\begin{tabular}{|c|c|c|c|c|c|c|c|}
\hline \multicolumn{6}{|c|}{ Mobile WiMAX } & \multicolumn{2}{|c|}{ Fixed WiMAX } \\
\hline $\begin{array}{l}\text { Channel } \\
\text { bandwidth, } \\
\text { duplexing: }\end{array}$ & Diversity: & $\begin{array}{l}\text { Nr. of antenna } \\
\text { Elements } \\
\text { (transmiss./ } \\
\text { reception): }\end{array}$ & $\begin{array}{c}\text { Space Time Coding } \\
\text { techniques } \\
\text { for coverage } \\
\text { enhancement: }\end{array}$ & $\begin{array}{c}\text { Frequency band: } \\
2.5 \mathrm{GHz}\end{array}$ & $\begin{array}{c}\text { Frequency band: } \\
\quad 3.5 \mathrm{GHz}\end{array}$ & $\begin{array}{l}\text { Channel } \\
\text { bandwidth, } \\
\text { duplexing: }\end{array}$ & $\begin{array}{c}\text { Frequency band: } \\
3.5 \mathrm{GHz}\end{array}$ \\
\hline \multirow{5}{*}{$\begin{array}{l}5 \mathrm{MHz} \\
\text { TDD }\end{array}$} & No & $1 \times 1$ & - & 3 & 3 & \multirow{5}{*}{$\begin{array}{c}3.5 \mathrm{MHz} \\
\text { TDD or } \\
\text { FDD }\end{array}$} & 7 \\
\hline & \multirow{4}{*}{ MIMO } & & - & 2 & 3 & & 5 \\
\hline & & $1 \times 2$ & $\checkmark$ & 2 & 3 & & 5 \\
\hline & & & - & 3 & 3 & & 7 \\
\hline & & $2 \times 2$ & $\checkmark$ & 2 & 2 & & 4 \\
\hline \multirow{5}{*}{$\begin{array}{l}10 \mathrm{MHz}, \\
\text { TDD }\end{array}$} & No & $101 \times 1$ & $\overline{-1}$ & $\bar{~} 4$ & $\overline{5}$ & \multirow{5}{*}{$\begin{array}{c}7 \mathrm{MHz}, \\
\text { TDD or FDD }\end{array}$} & 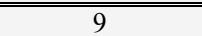 \\
\hline & \multirow{4}{*}{ MIMO } & $1 \times 2$ & - & 3 & 3 & & 7 \\
\hline & & $1 \times 2$ & $\checkmark$ & 3 & 3 & & 7 \\
\hline & & \multirow{2}{*}{$2 \times 2$} & - & 4 & 5 & & 9 \\
\hline & & & $\checkmark$ & 2 & 3 & & 5 \\
\hline
\end{tabular}

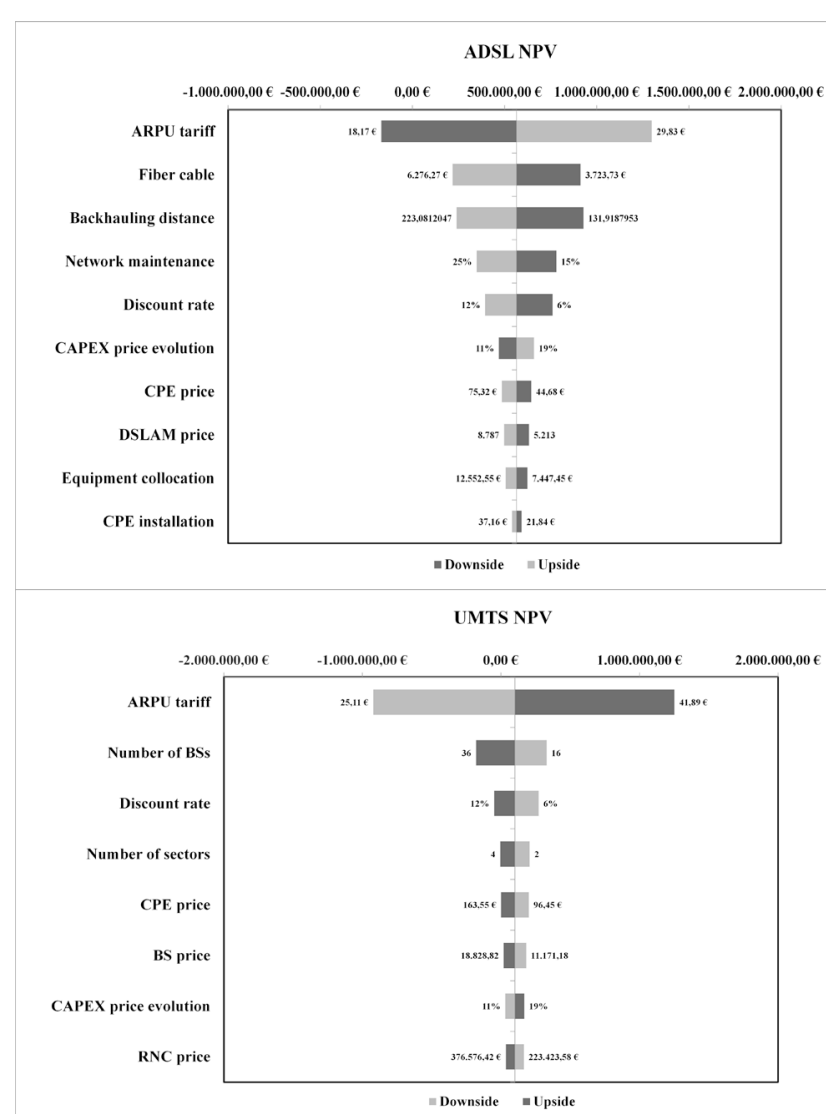

Figure 11 NPV sensitivity analyses of wired fixed and wireless mobile access technologies [40]

\subsection{Sensitivity and risk analyses results}

The parameters included in the conducted sensitivity and risk analyses of various wired and wireless, fixed and mobile access networks are:

- the discount rates;

- the number of broadband users;

- the network equipment, i.e. the DSLAM and the base station (BS) prices, the customer premises equipment (CPE) prices, and the service average revenue per user (ARPU) levels (for each parameter $50 \%$ deviations from the base assumptions are defined as the upper and the lower limits for the analyses);
- the backhauling distances / the number of BS sectors and the wireless access network spectral efficiency; - the backhauling access solutions.

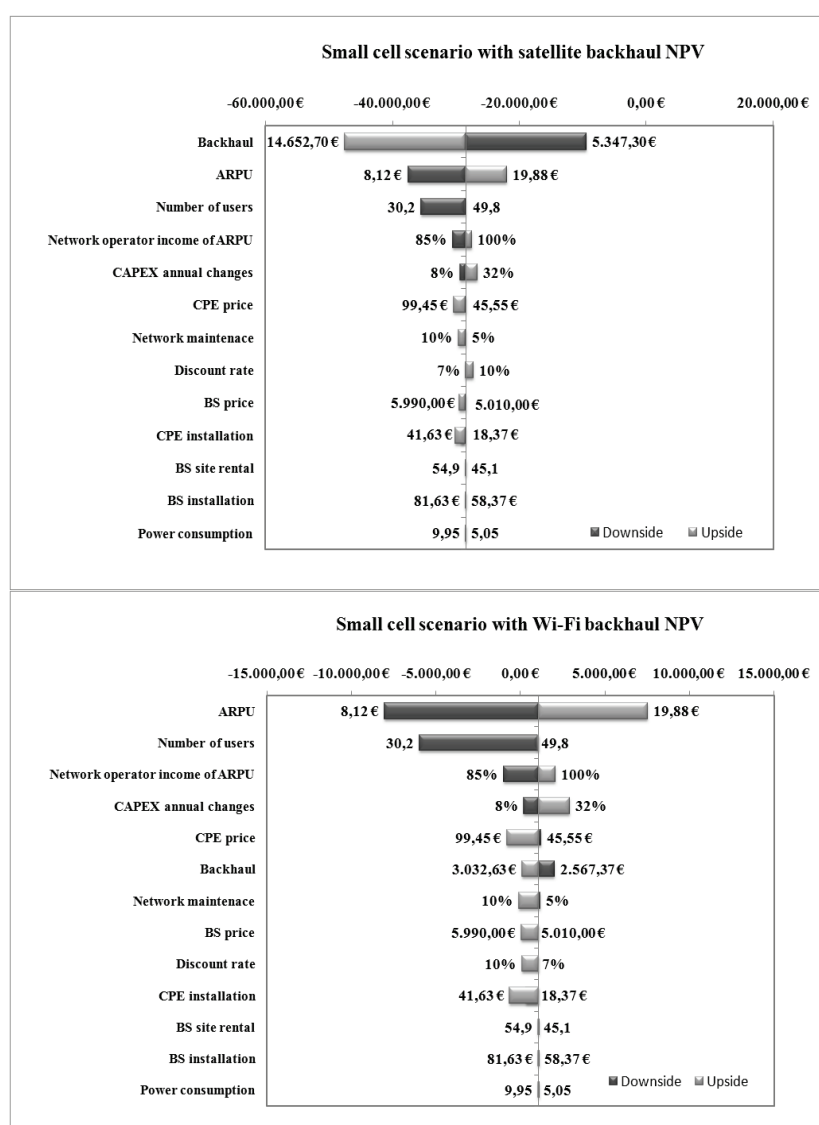

Figure 12 NPV sensitivity analyses for small cell access scenarios [45]

The conclusions based on the conducted sensitivity and risk analyses 'results are listed hereafter.

- The discount rates greatly affect the NPVs of the investment projects, as illustrated in Fig. 9.

- The increasement in the number of potential broadband users increases the profitability of the network deployment, i.e. the required investments per user decrease as the household density increases (the NPVs for different access technologies and different number of endusers are illustrated in Fig. 8). 
- The monthly ARPU and the equipment prices are the major contributors to the uncertainty in NPVs, as illustrated in Fig. 11.

- The longer backhauling, necessary when service and network operator's premises are far off, greatly incereases the broadband access costs and affects the NPVs of the investment project, as illustrated in Fig. 7.

- The backhaul access expenditures are the dominant contributors to the uncertainty in the NPV. Therefore, in wireless access scenarios the usage of backhaul access based on a license-exempt spectrum (e.g. Wi-Fi) is proposed, as illustrated in Fig. 12.

- The narrower channel bandwidths, the antenna diversity and the usage of adequate coding techniques for the coverage enhancement change the necessary number of BSs, as presented in Tab. 5, and affect the overall costeffectiveness of wireless access solutions, as illustrated in Fig. 10.

- The smaller the area to be covered, the less economical is the use of macrocell technology, as illustrated in Fig. 8, so the usage of small cells is adequate and cost-effective access solution for small rural settlements, as illustrated in Fig. 12.

- The BS elements for sectorised access are more expensive than the ones for omnidirectional access; hence additional sectors increase the overall capital expenditures and reduce the NPVs of the investment project, as illustrated in Fig. 7. Typical rural small cells are omnidirectional. It is better to meet the greater capacity requirements by implementing multiple omnidirectional small cells and extending rural area coverage than to sectorise a single site.

\section{Conclusion}

The new European initiatives for the rural broadband development define the application of broadband technologies as one of the priorities in the process of improving competitiveness of the European rural areas. In order to close the existing digital divide between the rural and the urban areas, the differences between those areas should be considered. Thus, while aiming at the further encouragement of broadband adoption in rural areas and the closure of the existing digital gap, the appropriate strategies for enhancing broadband adoption, like the inclusion of the end-users' requests for broadband services in the broadband solutions' techno-economic evaluation process, as proposed in this paper, should be considered.

In this paper, considering the broadband ecosystem elements' interconnection, the novel approach of the techno-economic modelling process for defining an adequate rural broadband access solutions is examined. The objective of the proposed model is related to the encouragement of rural residents to a further application of broadband technologies and services by introducing the broadband services compatible to their requests, which should result in the increase in the overall number of users in rural areas. Also, the increase in availability of broadband access infrastructure, based on the best business operator's strategies adoption, can encourage further broadband usage and should enable the reduction of the existing digital divide, as well.

Therefore, the proposed methodology connects analysed technically and economically oriented users' requests (for service quality, traffic volume, access speed, service price) and operators' requests (for the cost effectiveness of selected technical solutions). For this purpose, a new framework for analysing and modelling the explicitly defined users' requests is proposed and associated with the standard techno-economic modelling methods. The framework includes additional criteria based on both the interests of the operators and the requests of potential end users in rural areas. The obtained criteria are arranged and entered into the techno-economic modelling process, so that the profitability of the selected broadband access solutions can be determined afterwards.

The analyses of techno-economic aspects of implementing broadband access in rural areas define possible economic benefits of rural broadband implementation. Furthermore, the obtained results of the conducted techno-economic analyses imply several conclusions. First of all, fixed wireline access networks are the cost-effective broadband access solutions when certain access infrastructure components pre-exist. Moreover, the success of wireless technologies requires the technologies to reach the cost levels comparable to those of the wireline technologies that have long ago established its position in the broadband market. Furthermore, the results of the analyses show that the most critical success factor regarding the profitability of fixed wireless access network deployments in rural areas is the high price of the network equipment. This results from the large investments required in the early phases of network deployments when the number of broadband service users is low. Moreover, it is evident that the most critical success factor regarding the profitability of mobile wireless access network deployments in rural areas is mainly the high price of the annual spectrum license fees. Hence, the efficient spectrum management is essential in order to improve wireless broadband accessibility. However, wireless network deployments are necessary in rural areas where the availability of other alternative access technologies is limited. In sparsely populated rural areas not connected to fibre backbone networks, the wireless technologies may be a more cost-effective way to provide broadband access to households, as presented in the analyses. In these areas, however, the profitability is relatively poor for all analysed technologies.

Furthermore, the conducted analyses of the economic aspects of implementing broadband access demonstrate how the specificities of each particular type of rural areas affect the application of different broadband technologies. The obtained analyses results enable forecasting, investment decisions, the optimization and the control of rural broadband access investment risks. The model provides insight into critical factors affecting the broadband investment risks and assesses the probability of achieving the defined objectives. Since broadband implementation is extremely important for the future competitive development of rural areas, the content of these techno-economic analyses is a contribution to the achievement of strategic goals for developing rural areas. 


\section{Acknowledgements}

A part of the research was carried out within the Croatian Ministry of Science, Education and Sport's project "Broadband Internet access and Internet services in rural areas" (Grant number 165-0362027-1479) and the "Looking to the future 2020" project, led by the Croatian Regulatory Authority for Network Industries. Moreover, the presented results of the conducted techno-economic analyses are based on the research of several previously published analyses presented at the international conferences referenced in the Results chapter.

\section{References}

[1] Trkmana, P.; Blazica, B. J.; Turka, T. Factors of broadband development and the design of a strategic policy framework. // Telecommunications Policy. (2008). DOI: 10.1016/j.telpol.2007.11.001

[2] Peronard, J.-P.; Just, F. User motivation for broadband: A rural Danish study. // Telecommunications Policy. (2011). DOI: 10.1016/j.telpol.2011.06.008

[3] Yuguchi, K. The digital divide problem: An economic interpretation of the Japanese experience. // Telecommunications Policy. (2008). DOI: 10.1016/j.telpol.2008.02.006

[4] LaRose, R.; Greggb, J. L.; Stroverc, S.; Straubhaarc, J.; Carpenterd, S. Closing the rural broadband gap: Promoting adoption of the Internet in rural America. // Telecommunications Policy. (2007). DOI: 10.1016/j.telpol.2007.04.004

[5] Greenstein, S.; McDevitt, R. The broadband bonus: Estimating broadband Internet's economic value. // Telecommunications Policy. (2010).

[6] Kolko, J. Broadband and Local Growth. // Journal of Urban Economics. 71, 1(2012). DOI: 10.1016/j.jue.2011.07.004

[7] Holt, L.; Jamison, M. Broadband and Contributions to Economic Growth: Lessons from the US Experience. // Telecommunications Policy. (2009). DOI: 10.1016/j.telpol.2009.08.008

[8] Koutroumpis, P. The economic impact of broadband on growth: A simultaneous approach. // Telecommunications Policy. (2009). DOI: 10.1016/j.telpol.2009.07.004

[9] "Europe 2020: A Digital Agenda For Europe", Com(2010) 245, Communication from the Commission to the European Parliament, the Council, the European Economic and Social Committee and the Committee of the Regions, European Commission, Brussels, 2010.

[10] "Broadband Development Strategy in the Republic of Croatiain 2011 - 2015", Ministry of the Sea, Transport and Infrastructure of the Republic of Croatia, Zagreb, 2010.

[11] Peronard, J.-P.; Just, F. User motivation for broadband: A rural Danish study. // Telecommunications Policy. (2011). DOI: 10.1016/j.telpol.2011.06.008

[12] Michailidis, A.; Partalidou, M.; Nastis, S.; PapadakiKlavdianou, A.; Charatsari, C. Who goes online? Evidence of Internet use patterns from rural Greece. // Telecommunications Policy. (2011). DOI: 10.1016/j.telpol.2011.02.006

[13] Chaudhuri, A.; Flamm, K.Analysis of the Determinants of Broadband Access. // Telecommunications Policy. (2007).

[14] Bauer, J. M. Regulation, public policy, and investment in communications infrastructure. // Telecommunications Policy. (2010). DOI: 10.1016/j.telpol.2009.11.011

[15] Whitacre, B. The Diffusion of Internet Technologies to Rural Communities: A Portrait of Broadband Supply and Demand. // American Behavioral Scientist. 53, (2010). DOI: $10.1177 / 0002764210361684$
[16] Preston, P.; Cawley, A.; Metykova, M. Broadband and rural areas in the EU: From technology to applications and use. // Telecommunications Policy. (2007). DOI: 10.1016/j.telpol.2007.04.003

[17] First Releases and Statistical Reports of the Croatian Bureau of Statistics for the period 2002-2014, http://www.dzs.hr/default e.htm

[18] Goldfarb, A.; Prince, J. Internet Adoption and Usage Patterns are Different: Implications for the Digital Divide. // Information Economics and Policy. (2008). DOI: 10.1016/j.infoecopol.2007.05.001

[19] Prieger, J. E.; Hu, W-M. The Broadband Digital Divide and the Nexus of Race, Competition, and Quality. // Information Economics and Policy. 20, 2(2008). DOI: 10.1016/.infoecopol.2008.01.001

[20] "e-Croatia Program Enforcement Plan", studies and reports about available public Internet services, Central State

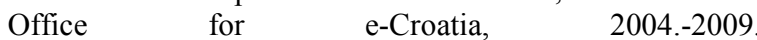
http://www.uprava.hr/default.aspx?id=13639

[21] Drouard, J. Computer Literacy, Online Experience or Socio-Economic Characteristics - What are the Main Determinants of Broadband Internet Adoption and Internet Usage. // Communications \& Strategies. 80, (2010).

[22] LaRose, R.; Strover, S.; Gregg, J. L.; Straubhaar, J. The impact of rural broadband development: Lessons from a natural field experiment. // Government Information Quarterly. 28, (2011). DOI: 10.1016/j.giq.2009.12.013

[23] Lee, S. A cross-country analysis of ubiquitous broadband deployment: Examination of adoption factors. // Doctoral dissertation, University of Florida, SAD, 2008.

[24] Andres, L.; Cuberes, D.; Diouf, M.; Serebrisky, T. The diffusion of the Internet: A cross-country analysis. // Telecommunications Policy, 2010. DOI: 10.1016/j.telpol.2010.01.003

[25] Usage of Information and Communications Technologies in Households and by Individuals. // Reports, Croatian Bureau of Statistics, Zagreb, 2007-2014.

[26] Proposal for a Regulation of the European Parliament and of the Council on measures to reduce the cost of deploying high-speed electronic communications networks. // European Commission, 2013/0080 (COD), Brussels, 2013.

[27] Kelly, T.; Rossotto, C. M. Broadband Strategies Handbook, The World Bank, Washington, 2012. DOI: 10.1596/978-08213-8945-4

[28] Smura, T. Techno-economic modelling of wireless network and industry architectures. // Doctoral dissertation, Aalto University, School of Electrical Engineering, Department of Communications and Networking, Espoo, Finland, 2012.

[29] Verdegem, P.; Marez, L. D. Rethinking determinants of ICT acceptance: Towards an integrated and comprehensive overview. // Technovation. 31, (2011). DOI: 10.1016/j.technovation.2011.02.004

[30] Grubesic, T. The Geodemographic Correlates of Broadband Access and Availability in the United States: A Longitudinal Analysis. // Telematics and Informatics. 21, 4(2004). DOI: 10.1016/j.tele.2004.02.003

[31] Laaksonen, P. Critical Factors of High-Speed Broadband Investments in Rural Areas from Perspective of Operators. // Master thesis, Aalto University, School of Electrical Engineering, Espoo, Finland, 2011.

[32] Katsianis, D. Telecommunications Networks Planning and Evaluation with Techno-Economic Criteria. // Doctoral dissertation, University of Athens, 2009.

[33] Verbrugge, S.; Casier, K.; Van Ooteghem, J.; Lannoo, B. Practical Steps in Techno-economic Evaluation of Network Deployment Planning. // IBCN White Paper, Belgian, 2009.

[34] Kantor, M. et al. General framework for techno-economic analysis of next generation access networks. // Proceedings 
of the 12th International Conference on Transparent Optical Networks, 2010. DOI: 10.1109/icton.2010.5549342

[35] Savage, S. J.; Waldman, D. Broadband Internet Access, Awareness and Use: Analysis of United States Household Data. // Telecommunications Policy, 2005. DOl: 10.1016/j.telpol.2005.06.001

[36] Gulin, D.; Tušek, B.; Žager, L. 'Poslovno planiranje, kontrola i analiza, RiF, Zagreb, 2004.

[37] Žagar, D.; Križanović, V.; Grgić, K. Analyses of Main Factors in Implementation of Broadband Internet in Croatian Rural Areas. // Proceedings of the $26^{\text {th }}$ International Conference Science in Practice, Osijek, Croatia, 2008.

[38] Žagar, D.; Križanović, V. Analyses and Comparisons of Technologies for Rural Broadband Implementation. // Proceedings of the $17^{\text {th }}$ International Conference on Software Telecommunications and Computer Networks, Hvar, Croatia, 2009.

[39] Križanović, V.; Grgić, K.; Žagar, D. Analyses and Comparisons of Fixed Access Technologies for Rural Broadband Implementation. // Proceedings of the $32^{\text {nd }}$ International Conference on Information Technology Interfaces, Cavtat-Dubrovnik, Croatia, 2010.

[40] Križanović, V.; Žagar, D.; Grgić, K. Techno-Economic Analyses of Wireline and Wireless Broadband Access Networks Deployment in Croatian Rural Areas. // Proceedings of the $11^{\text {th }}$ International Conference on Telecommunications, Graz, Austria, 2011.

[41] Križanović, V.; Žagar, D.; Martinović, G. Mobile Broadband Access Networks Planning and Evaluation Using Techno-economic Criteria. // Proceedings of the $34^{\text {th }}$ International Conference on Information Technology Interfaces, Cavtat-Dubrovnik, Croatia, 2012.

[42] Žagar, D.; Križanović, V.; Grgić, K. Business Case Assessments of Fixed and Mobile Broadband Access Networks Deployments. // Proceedings of the $20^{\text {th }}$ International Conference on Software, Telecommunications and Computer Networks, Split, Croatia, 2012.

[43] Križanović, V.; Žagar, D.; Grgić, K. Econometric Analysis of Demographic and Socio-Economic Factors Influencing Broadband Adoption in Croatian Rural Counties. // Proceedings of the $12^{\text {th }}$ International Conference on Telecommunications, Zagreb, Croatia, 2013.

[44] Križanović, V.; Žagar, D.; Rimac-Drlje, S.; Švedek, T. Business Models and Cost Optimization of Wireless Rural Broadband Access Implementation. // Proceedings of the $22^{\text {nd }}$ International Conference on Software, Telecommunications and Computer Networks, Split, Croatia, 2014.

[45] Križanović Čik, V.; Žagar, D.; Grgić, K. Optimised Broadband Internet Access Solutions for Digital Inclusion of Small Rural Communities. // Proceedings of the $13^{\text {th }}$ International Conference on Telecommunications, Graz, Austria, 2015.

\section{Authors' addresses}

Višnja Križanović Čik, PhD

Faculty of Electrical Engineering in Osijek

Kneza Trpimira 2B, Osijek

E-mail: vkrizano@etfos.hr

Drago Žagar, Full professor

Faculty of Electrical Engineering in Osijek

Kneza Trpimira 2B, Osijek

E-mail: drago.zagar@etfos.hr

Snježana Rimac-Drlje, Full professor

Faculty of Electrical Engineering in Osijek

Kneza Trpimira 2B, Osijek

E-mail: snjezana.rimac@etfos.hr 